\title{
ШЛЯХИ ЗАСТОСУВАННЯ РЕТРОСПЕКТИВНОГО ОПИТУВАННЯ В КОНТРОЛІ Й НАВЧАННІ ПЕРЕКЛАДУ МАЙБУТНІХ ФІЛОЛОГІВ
}

\author{
Король Т. Г. \\ кандидат педагогічних наук, доиент, \\ дочент кафедри української, іноземних мов та перекладу \\ Полтавський університет економіки і торгівлі \\ вул. Коваля, 3, Полтава, Україна \\ orcid.org/0000-0002-7240-6056 \\ koroltatyanalq@gmail.com
}

\author{
Ключові слова: \\ самоконтроль, рефлексія, \\ метакогнітивні вміння, \\ перекладацький процес, \\ перекладацький продукт, \\ прочес оволодіння \\ перекладаџькою \\ компетентністю, \\ альтернативний засіб \\ оцінювання.
}

Статтю присвячено проблемі реалізації самоконтролю в навчанні перекладу майбутніх філологів із застосуванням мультифункціонального альтернативного засобу контролю - ретроспективного опитувальника. Актуальність вивчення особливостей організації самоконтролю, насамперед, зумовлена запровадженням студентоцентрованого навчання, потребою у формуванні рефлексивних і регуляторних метакогнітивних навичок і вмінь студентів, необхідних для забезпечення ефективної навчальної й майбутньої професійної діяльності. Його ефективна реалізація має спиратися на спеціально розроблені засоби, що, 3 одного боку, дадуть змогу чітко структурувати й узгодити навчальну, перекладацьку й рефлексивну діяльність студентів, а 3 другого усвідомити й адекватно застосовувати критерії оцінки якості перебігу процесу перекладу та його продукту, процесу навчання та його результатів. У цьому контексті видається перспективною розробка й використання ретроспективного опитувальника, що завдяки ретельно розробленій багатоплановій структурі й регулярному застосуванню дає змогу впорядкувати процес здійснення самоконтролю й опанування відповідними навичками й уміннями майбутніми філологами. Крім того, його систематичне заповнення студентами після виконання кожного самостійного перекладацького завдання дає змогу запобігти академічній недоброчесності; з'ясувати ставлення студентів до тексту оригіналу й перекладу, забезпечуючи в такий спосіб інтенсивний зворотній зв'язок із викладачем, спонукати їх до самоспостереження, самоусвідомлення й самооцінки ефективності власної перекладацької діяльності, а також до детальнішого вивчення й інтерпретації тексту оригіналу та свідомого редагування й коригування тексту перекладу, визначити перелік актуальних перекладацьких проблем, представлених у конкретному тексті оригіналу для кожного окремого студента, оцінити дієвість застосованих ним когнітивних стратегій для їх розв'язання, узагальнити отримані у такий спосіб дані для визначення рівня складності пропонованого перекладацького завдання й укладення системи оцінювання результатів його виконання, створити умови для рефлексивного обговорення перекладацького завдання у парах та групах, відстежувати й аналізувати прогрес у навчанні перекладу кожного окремого студента й групи загалом шляхом систематизації отриманої в такий спосіб інформації. 


\title{
RETROSPECTIVE QUESTIONNAIRE: IMPLICATIONS FOR PROSPECTIVE PHILOLOGISTS' TRANSLATION TRAINING AND ASSESSMENT
}

\author{
Korol T. H. \\ Candidate of Pedagogical Sciences, Associate Professor, \\ Senior Lecturer at the Department of Ukrainian, Foreign Languages and Translation \\ Poltava University of Economics and Trade \\ Kovalia str., 3, Poltava, Ukraine \\ orcid.org/0000-0002-7240-6056 \\ koroltatyanalq@gmail.com
}

Key words:

self-assessment, reflection, metacognitive skills, translation process, translation product, translation competence acquisition, alternative evaluation tool.
This article is devoted to the problem of self-assessment arrangement in teaching translation to prospective philologists with the help of multifunctional alternative assessment tool, i.e. retrospective task-based questionnaire. First of all, the topicality of self-assessment peculiarity investigation is caused by the implementation of student-oriented approach to teaching and is closely connected with the need for the development of students' reflective and regulatory metacognitive skills, essential for their efficient current learning and future professional performance. Efficient self-assessment practice should be based on specifically developed tools. On the one hand, they should clearly structure and orchestrate students' learning, translation and reflective activities, and make them adopt and adequately apply qualitative criteria to assess translation process and product as well as learning process and outcomes. To this end, the development and use of retrospective taskbased questionnaire appears to be quite promising. Its thoroughly elaborated multi-aspect structure and regular application contribute to the self-assessment process arrangement and prospective philologists' relevant skills acquisition. In addition, its systematic completion by the students after translation task performance prevents academic plagiarism, reveals their attitude to the source and target texts, providing in such a way extensive feedback, urges them to self-observation, self-awareness, and self-evaluation of their own translation performance. Retrospective questionnaires encourage students to study and interpret the source text details, revise and edit the received target text with more diligence. Furthermore, they allow to determine the list of topical translation problems, represented in a particular source text for every student, and evaluate the appropriateness of the cognitive strategies, involved to solve them. Received in such a way data can be summarized in order to define the given translation task difficulty and develop its performance assessment method. Finally, retrospective questionnaire responses can provide the basis for both pair and group translation task reflective discussion, monitor and analyse students' progress in translation competence acquisition.
Постановка проблеми. У сучасній освітній парадигмі спостерігається стійка тенденція до домінування студентоцентристського підходу до навчання й, відповідно, контролю, що передбачає активну й відповідальну позицію студента в контексті навіть не опанування, а саме конструювання нових знань, навичок і вмінь, з одного боку, та його безпосередню участь у реалізації контролю перебігу й результатів такої діяльності - 3 другого. Це своєю чергою змушує викладачів зосередитися на вивченні шляхів та засобів організації ефективного самоконтролю в закладах вищої освіти (ЗВО), що набуває особливого значення в підготовці майбутніх філологів $з$ огляду на специфіку їхньої майбутньої професійної діяльності в галузі перекладу. Адже успішне надання перекладацьких послуг вимагає невпинного розвитку широкого спектра професійних компетентностей філолога, його здатності адекватно оцінювати власні можливості стосовно виконання поставленого професійного завдання, постійно контролювати свою діяльність безпосередньо у процесі перекладу й об'єктивно оцінювати якість отриманого перекладацького продукту. Отже, виникає гостра потреба в планомірному фор- 
муванні у студентів відповідних рефлексивних та регуляторних метакогнітивних навичок і вмінь у процесі викладання перекладу у вітчизняних закладах вищої освіти (ЗВО), що має обов'язково спиратися на ретельно розроблені засоби здійснення самоконтролю як своєрідної орієнтовної основи дії. Адже, на думку низки дослідників $[1 ; 2 ; 3]$, отримання адекватних результатів самоконтролю як безпосереднього показника успішності виконання цієї діяльності можливе лише за умови усвідомлення студентами чітких критеріїв оцінювання кожного окремого об'єкта та послідовності й змісту необхідних для їх застосування рефлексивних дій.

Проблема самоконтролю в навчанні перекладу, хоч і належить до одних із найактуальніших, мало представлена в сучасній методиці його викладання. Нині визначено роль самоконтролю в навчанні перекладу (Y. Fowler, Y. Lee) як засобу відстеження процесу опанування цієї складної білінгвальної діяльності; з'ясовано основні труднощі в його реалізації в процесі навчання (J. Fanghanel \& A. Voela), запропоновано використовувати різноманітні засоби 3 метою їх подолання: листи й шкали самооцінювання (M. Bartlomiejczyk, A. Schjoldager, M. Arumí \& O. Esteve), записи самоконтролю (M. N. Martínez \& A. Albir Hurtado), перекладацькі щоденники (O. Fox, M. Orlando), рефлексивні звіти (P. Pietrzak) й ретроспективні опитувальники (P. Pietrzak, F. Fernández \& P. Zabalbeasco). Саме останні, що здебільшого розглядалися як засоби формування окремих компонентів перекладацької стратегічної компетентності, на наш погляд, становлять неабиякий інтерес із точки зору організації самоконтролю в навчанні перекладу в умовах вітчизняних ЗВО за рахунок їх мультифункціональності.

Метою цієї статті $\epsilon$ розробка структури та змісту такого ретроспективного опитувальника й визначення можливих напрямів його застосування в навчанні перекладу майбутніх філологів.
Виклад основного матеріалу дослідження. Відповідно до вже попередньо запропонованої класифікації засобів самоконтролю в навчанні письмового перекладу за функцією та етапом застосування [4, с. 438], ретроспективний опитувальник належить до констатувальних проміжних засобів, оскільки передбачає надання відповідей на поставлені запитання після виконання окремого перекладацького завдання з метою самозвітування про характер здійсненої перекладацької діяльності та оцінки отриманого продукту перекладу чи результатів чергового етапу навчання задля обліку набутих перекладацьких знань, сформованих навичок і вмінь. Стосовно моменту його застосування у процесі виконання безпосереднього перекладацького завдання, то цей опитувальник заповнюється студентом після його фактичного завершення, на відміну від діагностичних й паралельних, що передують, діагностуючи потенційні труднощі та плануючи діяльність заздалегідь, i, відповідно, супроводжують перебіг виконання перекладу, відстежуючи його особливості [5].

3 точки зору експліцитності подачі об'єктів та критеріїв їх оцінювання, а також ступеня активності студента та детермінованості й розгорнутості його очікуваної реакції-відповіді ретроспективний опитувальник посідає проміжну позицію між завершеними за своїм змістом традиційними контрольними листами самооцінювання процесу й продукту перекладу та рефлексивними самозвітами, перекладацькими щоденниками й журналами з абсолютно відкритою й довільною структурою (див. рис. 1).

Відповідно, у процесі навчання ретроспективні опитувальники мають застосовуватися після періоду активного використання контрольних листів самооцінювання як своєрідний підготовчий керований етап на шляху до запровадження неструктурованих рефлексивних самозвітів, перекладацьких журналів і щоденників, що відповідає

Ступінь активності студента

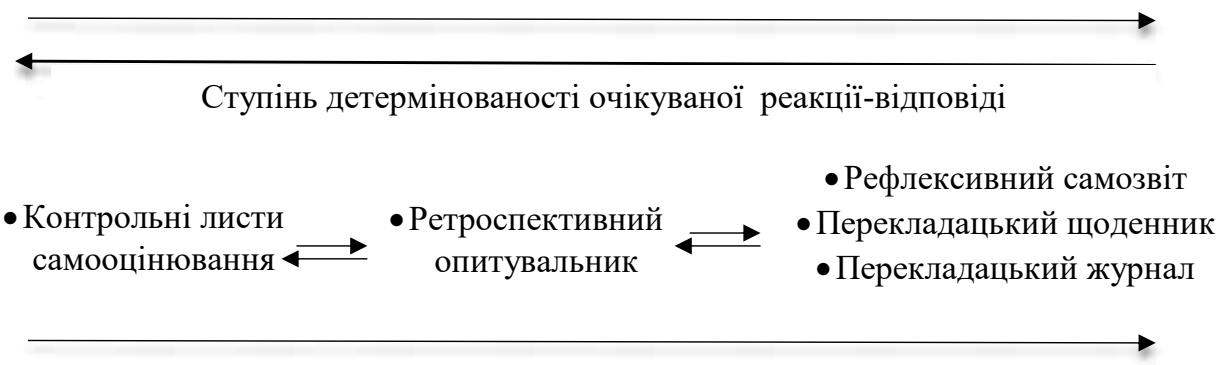

Ступінь розгорнутості очікуваної реакції-відповіді

Рис. 1. Градація засобів самоконтролю в навчанні перекладу за передбачуваним ступенем активності студента, детермінованості й розгорнутості очікуваної відповіді 
концепції поступового опанування відповідними навичками й уміннями шляхом послідовного подолання посильних труднощів, у тому числі й за підтримки та допомоги викладача й колег, i нарощування рівня складності завдання, де кожен попередній етап закладає підвалини для реалізації наступного [6, с. 46].

При цьому структура ретроспективного опитувальника має бути гнучкою, дозволяти як додавання, так і вилучення окремих питань, тим самим репрезентуючи специфіку функціонування завершеного й продуктивного циклу зворотного зв'язку в контролі й самоконтролі за рахунок двосторонньої рефлексії з приводу цього процесу як із боку студента, так і викладача. Оскільки основною метою використання ретроспективного опитувальника в навчанні письмового перекладу $є$ заохочення студентів до розвитку власних рефлексивних навичок i вмінь шляхом їх безпосереднього застосування, його структура й зміст мають узгоджуватися 3 основними об'єктами рефлексії в навчанні перекладу, а саме: 1) процес перекладу; 2) продукт перекладу; 3) процес навчання $[3 ; 5]$. Цілком логічно пропонуємо доповнити цей перелік проміжними результатами навчання, що передбачають усвідомлення студентами набутих ними знань, навичок і вмінь у процесі виконання окремого перекладацького завдання.

У процесі укладення структури і змісту ретроспективного опитувальника необхідно враховувати той факт, що пусковим механізмом рефлексивної діяльності є ситуація невизначеності й вибору, яка спонукає студентів до пошуку відповіді на запитання, продукування гіпотез, їх теоретичного чи емпіричного доведення або спростування. Для того щоб рефлексія була ефективною, вона має керуватися зацікавленістю та допитливістю. При цьому рефлексивна діяльність у межах навчання перекладу має бути спрямована не на пошук правильної відповіді, а на формулювання перекладацьких і навчальних проблем, аргументів та обгрунтувань прийнятих перекладацьких рішень, які завжди матимуть індивідуальний характер і відрізнятимуться в межах однієї академічної групи [3]. Внаслідок цього виникає необхідність пояснити студентам цінність відповідей на запитання ретроспективного опитувальника 3 точки зору особистого перекладацького досвіду, що зумовлює їхній індивідуальний характер. При цьому з'являється супутня проблема: чи мають оцінюватися відповіді на запитання опитувальника викладачем чи, може, вони взагалі мають лишатися анонімними, як це пропонують деякі дослідники [3]? На наш погляд, ретроспективні опитувальники, що слугують альтернативними засобами контролю в навчанні перекладу, мають чітко ідентифікувати їхнього автора й за певних обставин підлягати як безпосередньому, так й опосередкованому оцінюванню. Адже творчий підхід, розгорнутість й обгрунтованість відповідей студентів свідчать про активнішу рефлексивну діяльність $i$, як мінімум, ретельну роботу над заповненням опитувальника, а, як максимум, корелюють 3 ефективнішим виконанням перекладацької діяльності студентів, за даними деяких емпіричних досліджень [7], з якими важко не погодитись. Тому пропонуємо попередньо оцінювати відповіді студентів на запитання ретроспективного опитувальниками за кількісними (повнота заповнення) та якісними критеріями (адекватність поданої відповіді, поставленим запитанням, іiі розгорнутість та аргументованість) хоча б з метою прогнозування якості виконаного перекладу й фокусування особливої уваги на тих його фрагментах, які прокоментовано студентами у відповідях на запитання ретроспективного опитувальника, під час його перевірки й оцінювання. Отримані результати так чи інакше мають доповнювати результати оцінювання тексту перекладу, допомагаючи підтвердити чи спростувати усвідомленість/випадковість вдалих перекладацьких рішень студентів та збагнути причини допущених помилок й вжити заходів щодо їх профілактики в майбутніх перекладах.

Орієнтовну структуру такого ретроспективного опитувальника для заповнення студентами після виконання окремого самостійного перекладацького завдання з прикладами запитань наводимо в таблиці 1.

На наш погляд, подана вище структура ретроспективного опитувальника дає змогу належним чином впорядкувати й спрямувати саморефлексію й самоконтроль студентів. Запитання, що належать до кожного з блоків, можуть і мають трансформуватися, вилучатися й додаватися 3 огляду на попередні відповіді студентів у процесі навчання.

Висновки. Отже, в глобальному розумінні використання ретроспективних опитувальників запропонованої структури та змісту мають сприяти створенню умов для саморефлексії студентів, підвищуючи тим самим ефективність навчання перекладу, в тому числі й сприяючи розвитку їхньої самосвідомості і саморегуляції, критичного мислення, а також формуванню звички аналізувати процес і продукт своєї перекладацької й навчальної діяльності, контролювати й коригувати їх перебіг, оцінювати їхні продукти й результати, формулювати перспективні цілі для подальшого вдосконалення та розвитку.

Крім того, їх систематичне заповнення студентами після виконання кожного самостійного перекладацького завдання дає змогу запобігти академічній недоброчесності, пов'язаній $з$ широ- 
Таблиця 1

Узагальнена структура ретроспективного опитувальника для контролю й навчання перекладу

\begin{tabular}{|c|c|}
\hline Змістовий компонент & Приклад запитань, типових для цього блоку \\
\hline 1. Особиста інформація & $\begin{array}{l}\text { - Your name and surname } \\
\text { - Article title }\end{array}$ \\
\hline $\begin{array}{l}\text { 2. Процес виконання } \\
\text { перекладу }\end{array}$ & $\begin{array}{l}\text { - How many times have you read the source text to start formulating its sense and } \\
\text { contents with the help of the target language means? } \\
- \text { Which dictionaries and other references sources did you use to find and select } \\
\text { proper translation equivalents and solve faced translation problems? } \\
- \text { How much time have you spent on translation performance }\end{array}$ \\
\hline 3. Перекладацький продукт & $\begin{array}{l}\text { - Highlight the most difficult for translation source text segments with yellow colour. } \\
\text { Explain your choice, please. } \\
\text { - Highlight the most successful target text segments from your personal point of view } \\
\text { with green colour. Explain your choice, please. } \\
\text { - Have you managed to create equivalent and adequate target text according to your } \\
\text { translation brief? Why or why not? }\end{array}$ \\
\hline 4. Процес навчання & $\begin{array}{l}\text { - Do you know what kind of translation knowledge, skills and experience you are } \\
\text { supposed to acquire performing this translation task? } \\
- \text { What skills do you need to develop or improve in order to perform better } \\
\text { translations? }\end{array}$ \\
\hline $\begin{array}{l}\text { 5. Проміжний результат } \\
\text { навчання }\end{array}$ & $\begin{array}{l}\text { - What have you learnt about performing this translation? } \\
\text { - What have you learnt to do performing this translation? }\end{array}$ \\
\hline
\end{tabular}

ким застосуванням інформаційних технологій як для практики тривіального копіювання чужих робіт, так і бездумного застосування можливостей машинного перекладу. На локальному рівні ретроспективні опитувальники дають змогу 3'ясувати ставлення студентів до тексту оригіналу (цікавість, складність тощо) й перекладу (задоволеність/незадоволеність якістю продукту своєї діяльності), забезпечуючи у такий спосіб інтенсивний зворотний зв'язок із викладачем. Заповнення ретроспективних опитувальників має спонукати студентів до детальнішого вивчення й інтерпретації тексту оригіналу та свідомого редагування й коригування тексту перекладу. Це своєю чергою дає змогу визначити перелік актуальних перекладацьких проблем, представлених у конкретному тексті оригіналу для кожного окремого студента, й оцінити діє- вість застосованих ним когнітивних стратегій для їх розв'язання. Узагальнення отриманих у такий спосіб даних може бути використане для визначення рівня складності пропонованого перекладацького завдання й укладення системи оцінювання результатів його виконання. Відповіді студентів мають стати відправною точкою для рефлексивного обговорення перекладацького завдання в парах та групах. Їх систематичний аналіз дасть змогу відстежувати, аналізувати й прогнозувати прогрес у навчанні перекладу кожного окремого студента й групи загалом.

Наступним кроком має стати укладення таких ретроспективних опитувальників для навчання й контролю різних видів письмового перекладу 3 урахуванням їхньої специфіки, а також емпірична перевірка ефективності цих засобів самоконтролю в навчальному процесі.

\section{Література}

1. Blanche P., Merino B. Self-assessment of Foreign-language Skills: Implications for Teachers and Researchers. Language Learning. 1989. Vol. 39, No. 3. P. 313-340.

2. Bartlomiejczyk M. Interpreting Quality as Perceived by Trainee Interpreters. The Interpreter and Translator Trainer. 2007. Vol. 1, No. 2. P. 247-267.

3. Pietrzak P. Scaffolding student self-reflection in translator training. Translation and Interpreting Studies. 2019. Vol. 14(3). P. 416-436.

4. Король Т.Г. Засоби реалізації самоконтролю в навчанні письмового перекладу майбутніх філологів. «Ad orbem per linguas. До світу через мови» : матеріали Міжнар. наук.-практ. конф. «Світ як інтертекст», Київ, 17-18 червня 2020 р. Київ : Видавничий центр КНЛУ, 2020. С. 437-439.

5. Pietrzak P. The potential of reflective translator learning. inTRAlinea. 2019. Special Issue: New Insights into Translator Training. URL: http://www.intralinea.org/specials/article/2431 (Last accessed: 25.08.2020).

6. Kiraly D. A Social Constructivist Approach to Translator Education. Empowerment from Theory to Practice. Manchester: St. Jerome, 2000. 215 p.

7. Fernández F., Zabalbeascoa P. Correlating trainees' translating performance with the quality of their etacognitive self-evaluation. Perspectives: Studies in Translatology. 2012. Vol. 20, No. 4. P. 463-478. 


\section{References}

1. Blanche, P. \& Merino, B. (1989). Self-assessment of Foreign-language Skills: Implications for Teachers and Researchers. Language Learning, 39 (3), 313-340.

2. Bartlomiejczyk, M. (2007). Interpreting Quality as Perceived by Trainee Interpreters. The Interpreter and Translator Trainer, 1 (2), 247-267.

3. Pietrzak, P. (2019). Scaffolding student self-reflection in translator training. Translation and Interpreting Studies, 14(3), 416-436.

4. Korol, T.H. (2020). Zasoby realizaciji samokontrolju v navchanni pysjmovogho perekladu majbutnikh filologhiv. [Self-assessment tools in prospective philologists' translation training]. Proceedings of International Scientific and Practical Conference “Ad orbem per linguas. Do svitu cherez movy”. K.: Vydavnychyj centr KNLU. P. 437-439. (in Ukr.).

5. Pietrzak, P. (2019). The potential of reflective translator learning. inTRAlinea. Special Issue: New Insights into Translator Training. Retrieved 20/08/2020, from http://www.intralinea.org/specials/article/2431.

6. Kiraly, D. (2000). A Social Constructivist Approach to Translator Education. Empowerment from Theory to Practice. Manchester: St. Jerome.

7. Fernández, F. \& Zabalbeascoa, P. (2012). Correlating trainees' translating performance with the quality of their etacognitive self-evaluation. Perspectives: Studies in Translatology, 20(4), 463-478. 